\title{
Efek Stimulasi Taktil Kinestetik erhadap Perkembangan Bayi Berat Badan Lahir Rendah
}

\author{
Dwi Hastuti, Juju Juhaeriah \\ STIKes Jendral Ahmad yani \\ E-mail:dwi.hastuti@gmail.com
}

\begin{abstract}
Abstrak
Perkembangan Bayi BBLR berisiko mengalami keterlambatan karena kondisi berat badan kurang dari 2500 gram, sehingga bayi mengalami proses adaptasi fisiologi yang berat. Salah satu proses adaptasi fisiologi yang harus tercapai pada BBLR adalah sistem thermoregulasi, pernapasan dan kardiovaskular. Bayi merupakan masa kritis (critical period) dimana merupakan waktu spesifik ketika sebuah peristiwa yang diberikan, atau ketiadaannya memiliki dampak terbesar terhadap perkembangan. Tujuan penelitian ini adalah mengidentifikasi efektifitas stimulasi taktilkinestetik terhadap perkembangan fisiologis (Suhu, Respirasi, Denyut Jantung) dan Berat Badan Bayi BBLR. Penelitian menggunakan desain quasi-eksperimental, pre-test dan post-test non-equivalent control group 30 bayi BBLR diambil dengan teknik probability sampling. Intervensi stimulasi taktil-kinestetik dilakukan sekali dalam sehari selama 5 hari. Lembar observasi dan prosedur stimulasi taktil-kinestetik digunakan sebagai instrumen penelitian. Data tersebut dianalisa menggunakan uji Man Whitney dan uji $t$ independent. Hasil uji statistik menunjukkan terdapat perbedaan yang signifikan perkembangan fisiologis suhu setelah intervensi (Post) pada Kelompok Intervensi dan Kontrol ( $p$ value 0,000); ada perbedaan yang signifikan Pernapasan Bayi BBLR setelah perawatan (Post) pada Kelompok Intervensi dan Kontrol ( $p$ value 0,037); ada perbedaan yang signifikan Denyut Jantung Bayi BBLR setelah perawatan (Post) pada KelompokIntervensidan Kontrol ( value 0,000); tidak ada perbedaan Berat Badan Bayi BBLR setelah perawatan (Post) pada Kelompok Intervensi dan Kontrol $(p$ value 0,155).
\end{abstract}

Kata kunci: BBLR, perkembangan, Stimulasi Taktil-kinestetik.

\section{Effect of Tactile-Kinesthetic Stimulation to Development of Low Birth Weight Babies}

\begin{abstract}
Low Birth Weight (LBW) in infant has risk of developmental delay due to conditions weighing less than 2500 grams, so that the infant suffered severe physiological adaptation process. One of the physiological adaptation processes that must be reached on LBW is thermoregulation system, respiratory and cardiovascular. Infant is a critical period which is a specific time when a given event, or lack thereof has the greatest impact on the development. The purpose of this study is to identify the effectiveness of tactile-kinesthetic stimulation to the development of physiological (temperature, respiration, heart rate) and Weight Infants LBW. The study used a quasi-experimental design, pre-test and post-test non-equivalent control group $30 \mathrm{LBW}$ infants taken with probability sampling technique. Intervention tactile-kinesthetic stimulation is done once a day for 5 days. Observation sheet and tactile-kinesthetic stimulation procedures is used as a research instrument. Data were analyzed using Man Whitney test and independent $t$ test. Statistical analysis showed significant differences physiological development of temperature after the intervention (Post) in the intervention and control groups ( $\mathrm{p}$ value 0,000); No significant differences Babies Respiratory LBW after treatment (Post) in the intervention and control groups (p value 0,037); No significant differences Heartbeat LBW infants after treatment (Post) in the intervention and control groups (p value 0,000); there is no difference Weight LBW infants after treatment (Post) in the intervention and control groups ( $\mathrm{p}$ value 0.155$)$.
\end{abstract}

Keywords: Development, low birth weight, tactile-kinesthetic stimulation. 
Dwi Hastuti: Hubungan IMT dan Kadar Albumin berhubungan dengan Penyembuhan Luka

\section{Pendahuluan}

Menurut Papalia, Olds, \& Feldman (2013) Bayi Berat Badan Lahir Rendah (BBLR) adalah Bayi yang lahir dengan berat badan $<$ 2500 gram. BBLR menjadikan bayi berisiko tidak saja untuk komplikasi neonatal, namun juga untuk faktor risiko tinggi lainnya seperti gangguan perkembangan yang dapat ditunjukkan dengan respon fisiologis maupun perilaku bayi (Wong, HockenberryEaton, Wilson, Winkelstein \& Schwartz, 2009). Bayi BBLR mengalami keimmaturan organ tubuhnya sehingga BBLR merupakan indikasi kuat risiko tinggi terhadap mortalitas, morbiditas maupun gangguan terhadap perkembangannya (Lissauer \& Faranoff, 2009).

Kondisi BBLR menyebabkan organ tubuh belum dapat berfungsi secara sempurna, sehingga penyesuaian fungsi organ terhadap perubahan kondisi dari intrauteri ke kondisi lingkungan di luar rahim sangat sulit bagi bayi (Wong, Hockenberry-Eaton, Wilson, Winkelstein \& Schwartz, 2009). Bayi didalam intrauterin mendapatkan kehangatan, ketenangan, sentuhan sehingga membuat bayi dapat berkembang dengan baik. Pada kondisi BBLR harus mengalami adaptasi intrauterin ke ekstrauterin secara dini sehingga memerlukan perjuangan untuk dapat bertahan secara normal. BBLR mengalami proses adaptasi yang besar terkait dengan maturasi dari organ sistem tubuh, sehingga mengakibatkan penurunan perkembangan fisiologis bayi (Bobak, Lowdermilk, \& Jensen, 2005).

Peran petugas kesehatan dalam hal ini adalah memberikan asuhan keperawatan secara komprehensif yang dinilai dari semua kebutuhan BBLR. Kebutuhan perawatan yang diberikan tidak hanya menghindari komplikasi penyakit, namun dituntut dapat memfasilitasi kebutuhan terkait pertumbuhan dan perkembangan neonatus. Banyak intervensi perkembangan yang dapat meningkatkan kesehatan neonatus salah satunya yaitu memberikan stimulasi taktil-kinestetik (Wong, HockenberryEaton, Wilson, Winkelstein \& Schwartz, 2009). Mekanisme efek pijat bayi antara lain pengeluaran beta endorphin yang memengaruhi mekanisme pertumbuhan dan perkembangan bayi, aktifitas nervus vagus memengaruhi mekanisme absorbsi makanan berhubungan dengan peningkatan enzim gastrin dan insulin serta produksi insulin yang dapat meningkatkan daya tahan tubuh (Kusmini, Nurul, M., Sutarmi, 2014).

Asuhan perkembangan memberikan kemudahan proses adaptasi BBLR terhadap lingkungan ekstrauterin yang meliputi pemenuhan kebutuhan secara fisiologis, social, psikososial, emosional yang dapat memfasilitasi pertumbuhan dan perkembangan bayi BBLR secara optimal. Asuhan perkembangan Stimulation tactilkinestetic dinilai mampu mempertahankan respon fisiologis bayi sehingga dapat beradaptasi dengan baik.Terapi pijat yang berbentuk sentuhan dengan tekanan moderat sebagai intervensi yang meningkatkan pertumbuhan dan sekaligus mengurangi stres karena BBLR menunjukkan respon perilaku yang terkait dengan stres harian rawat inap dan prosedur medis (Anand, 2005 dalamHernandez-Reif, Diego \& Field, 2007).

BBLR adalah bayi yang lahir dengan berat badan $<2500$ gram (Papalia, Olds, \& Feldman (2013). Beberapa penyebab dari BBLR Menurut Henderson \& Macdonald (2005) adalah (1) Faktor ibu (2) Faktor janin (3) Faktor plasenta (4) Faktor lingkungan.

Bayi Berat Badan Lahir Rendah membutuhkan perawatan, dukungan respirasi, termoregulasi, perlindungan terhadap infeksi, nutrisi, konservasi energi, perawatan kulit, dan asuhan perkembangan.

Asuhan perkembangan pada bayi BBLR dapat diberikan melalui stimulasi. Stimulasi bayi adalah intervensi perkembangan pada bayi dengan melibatkan lingkungan yang dapat meningkatkan perkembangan perseptual, sensorimotor, kognitive, language dan sosial emosional pada bayi (Reynolds \& Janzen, 2007). Bila kondisi bayi sudah cukup maju (kondisi stabil) dapat dilakukan intervensi perkembangan. Beberapa aktivitas akan di individualisasi sesuai petunjuk, temperamen, keadaan, organisasi tingkah laku, dan kebutuhan khusus masingmasing bayi. Periode intervensi singkat dan tipe intervensi pendek digunakan untuk mentolerir kondisi stres yang mungkin dapat muncul pada bayi akibat stimulasi yang diberikan. Tipe dan durasi setiap 
Dwi Hastuti: Hubungan IMT dan Kadar Albumin berhubungan dengan Penyembuhan Luka

stimulasi disesuaikan berdasarkan individu, dan orang tua dilibatkan seawal mungkin untuk mempelajari mengenai kebutuhan perkembangan khusus bayi mereka (Wong, Hockenberry-Eaton, Wilson, Winkelstein \& Schwartz, 2009).

Bayiyangbaru lahir sangat sensitifterhadap sentuhan, terutama di wajah, tangan, telapak kaki, dan perut. Pemberian stimulasi taktilkinestetik bersifat sebagai sentuhan sehingga dapat meningkatkan perkembangannya. Sentuhan dan elusan lembut pada kulit bayi sangatlah bermanfaat pada bayi-bayi BBLR. Sentuhan dapat meningkatkan berat badan bayi, meningkatkan keaktifan bayi, serta dapat membantu bayi sembuh dan keluar dari rumah sakit (Meggit, 2012). Stimulasi taktilkinestetik adalah istilah terapi pijat yang lebih baik dan efektif karena melibatkan sentuhan ringan (belaian ringan pada daerah atas kepala sampai dengan kaki). Stimulasi taktilkinestetik merupakan Intervensi pelengkap yang berbentuk terapi pijat dengan tekanan moderat yang terdiri dari fleksi dan ekstensi anggota badan dalam posisi terlentang; dan merupakan intervensi yang efektif dalam pengembangan perilaku motorik neonatus BBLR (Aliabadi \& Askary, 2013).

Pemberian stimulasi taktil-kinestetik dalam meningkatkan perkembangan neonatus BBLR menunjukkan plastisitas. Banyak kemampuan dapat ditingkatkan secara signifikan dengan latihan, dalam hal ini memberikan stimulasi termasuk dalam kegiatan latihan dan pengalaman. Pengalaman dinilai Memengaruhi perkembanagn otak. Setiap pengalaman baru membentuk perilaku. Perilaku merupakan hasil dari pengalaman atau adaptasi terhadap lingkungan; teori belajar menekankan pada peran lingkungan yang dapat diramalkan dalam memunculkan perilaku yang teramati; pembelajaran yang diamati didasarkan pada asosiasi sebuah stimulus yang akan memengaruhi respon khusus terhadap peningkatan perkembangan fisiologis bayi lebih stabil (Papalia, Olds \& Fieldman, 2013).

\section{Metode Penelitian}

Metode penelitin ini adalah quasi eksperimental dengan Pre test and post test nonequivalent kontrol group. Populasi dalam penelitian ini adalah bayi BBLR yang dirawat di ruang perinatology RSUD Soreang dengan tehnik probability samplin. Sampel diambil berdasarkan kriteria yaitu (1) Bayi lahir dengan berat badan $>1500$ gram sampai $<2500$ gram, (2) Bayi tidak ada kelainan kongenital (3) Bayi tidak mendapatkan terapi oksigen (3) Bayi tidak dehidrasi. Jumlah perhitungan sampel penelitian ini adalah 15 bayi untuk kelompok Intervensi dan 15 bayi untuk kelompok Kontrol. Proses pengambilan sampel dibagi menjadi 2 tahapan. Tahapan pertama 15 bayi pertama yang sesuai dengan kriteria semua diambil sebagai kelompok kontrol, dan tahapan kedua 15 bayi yang berikutnya dirawat dan sesuai kritera semua diambil sebagai kelompok intervensi.

Setiap subjek yang memenuhi kriteria inklusi peneliti langsung meminta inform consent dan melakukan proses pengumpulan data dengan cara menilai perkembangan bayi langsung pada kelompok control dengan menilai perkembangan fisiologis hari ke-1 perawatan dan hari ke-6 perawatan tanpa dilakukan stimulasi taktil-kinestetik dan pada kelompok intervensi hari ke- 1 sebelum melakukan stimulasi taktil-kinestetik dan hari ke-6 setelah melakukan intervensi stimulasi taktil-kinestetik. Stimulasi taktil-kinestetik dilakukan 1x perhari selama 5 hari. Hal ini didasarkan pada hasil penelitian sebelumnya oleh Hernandez-Reif, Diego\& Field, (2007) dimana dalam penelitian ini dijelaskan bahwa stimulasi taktil-kinestetik memberikan efek positif pada perilaku neonatus kecil setelah 5 hari intervensi dimana memiliki parameter fisiologis lebih baik dan memberikan perilaku adaptif yang lebih baik dibandingkan dengan neonatus yang tidak diberikan stimulasi yang ditunjukkan oleh adanya respon peningkatan perkembangan bayi yang dikarenakan proses tercapainya adaptasi regulasi bayi lebih cepat. Alat pengumpulan data penelitian dengan Lembar observasi untuk melihat perkembangan BBLR yang dilihat dari respon fisiologis (Suhu, Respirasi, Denyut Jantung) dan perubahan berat badan. Instrumen prosedur stimulasi taktilkinestetik, diadopsi menurut Kachoosangry \& Aliabadi (2011); Hernandez-Reif, Diego \& Field (2007); Wong, Hockenberry-Eaton, Wilson, Winkelstein \&Schwartz (2008). 
Dwi Hastuti: Hubungan IMT dan Kadar Albumin berhubungan dengan Penyembuhan Luka

Sebelum dilakukan uji analis untuk mengetahui perbedaan rerata skor perkembangan fisiologis dan BB Bayi (BBLR) pada kelompok Intervensi dan Kontrol sebelumnya dilakukan uji normalitas data dengan menggunakan KolmogorovSmirnov. Dimana dilihat dari nilai $p$ value jika hasil Kolmogorov-Smirnov nilai $p$ value $>$ 0,05 maka distribusi data adalah normal dan jika nilai $p$ value $\leq 0,05$ distribusi data adalah tidak normal. Berdasarkan hasil uji normalitas data pada sub variabel Suhu pre pada Intervensi dan kontrol berdistribusi tidak normal sehingga untuk menguji perbedaan perkembangan fisiologis suhu Bayi BBLR pada kelompok Intervensi dan Kontrol di analisis menggunakan uji Mann-Whitney Test, Hasil uji normalitas pada respirasi pre, denyut jantung pre, dan berat badan pre baik pada kelompok Intervensi maupun Kontrol data berdistribusi normal, sehingga untuk menguji perbedaan perkembangan fisiologis tersebut di analisis menggunakan uji $t$ independen. Berdasarkan hasil uji normalitas terhadap Suhu post pada kelompok intervensi data berdistribusi tidak normal dan pada kontrol data berdistribusi normal. Respirasi post pada intervensi dan kontrol data berdistribusi tidak normal, sehingga untuk menguji perbedaan perkembangan fisiologis tersebut dapat di analisis menggunakan Mann-Whitney Test, sedangkan hasil uji normalitas pada denyut jantung post kelompok intervensi dan kontrol data berdistribusi normal, pada berat badan post kelompok intervensi dan kontrol data berdistribusi normal, sehingga untuk menguji perbedaan perkembangan fisiologis tersebut di analisis menggunakan uji $t$ independen.

\section{Hasil Penelitian}

Penelitian yang telah dilakukan pada tanggal 28 Februari 2015 sampai dengan 20 Juni 2015 didapatkan hasil penelitian sebagai berikut: Hasil analisis Tabel 1. didapatkan bahwa mean rank Suhu Bayi BBLR sebelum intervensi (Pre) pada Intervensi adalah 16,03 sedangkan pada Kontrol adalah 14,97. Hasil uji statistik didapatkan nilai $p$ value 0,735 , berarti pada alpha $5 \%$ terlihat tidak ada perbedaan Suhu Bayi BBLR sebelum intervensi (Pre) baik pada Kelompok Intervensi maupun Kelompok Kontrol.

Hasil analisis Tabel 2. didapatkan bahwa sebelum intervensi (Pre) rata-rata Respirasi (RR) pada Intervensi adalah 51,80 dengan standar deviasi 5,56 sedangkan pada kontrol adalah 51,27 dengan standar deviasi 5,62. Hasil uji statistik didapatkan nilai $p$ value 0,796 , berarti pada alpha 5\% terlihat tidak ada perbedaan Respirasi BBLR sebelum

Tabel 1 Perbedaan Perkembangan Fisiologis (Suhu) Bayi BBLR sebelum (Pre) pada Kelompok Intervensi dan Kontrol di RSUD Soreang Tahun 2015

\begin{tabular}{lllll}
\hline $\begin{array}{c}\text { Perkembangan } \\
\text { Fisiologis }\end{array}$ & N & Mean Rank & P value & \\
\hline Suhu & Intervensi & 15 & 16,03 & 0,735 \\
& Kontrol & 15 & 14,97 & \\
\hline
\end{tabular}

Tabel 2 Perbedaan Perkembangan Fisiologis (Respirasi, Denyut Jantung) dan BB Bayi BBLR Sebelum (Pre) pada Kelompok Intervensi dan Kontrol di RSUD Soreang Tahun 2015

\begin{tabular}{clccccc}
\hline $\begin{array}{c}\text { Perkembangan } \\
\text { Fisiologis }\end{array}$ & Mean & SD & SE & P Value & N & \\
\hline RR & Intervensi & 51,80 & 5,56 & 1,43 & 0,796 & 15 \\
& Kontrol & 51,27 & 5,62 & 1,45 & & 15 \\
DJ & Intervensi & 127,00 & 6,14 & 1,59 & 0,666 & 15 \\
& Kontrol & 127,87 & 4,63 & 1,19 & & 15 \\
BB & Intervensi & 2128,33 & 207,21 & 53,50 & 0,945 & 15 \\
& Kontrol & 2133,33 & 184,84 & 47,73 & & 15 \\
\hline
\end{tabular}


Dwi Hastuti: Hubungan IMT dan Kadar Albumin berhubungan dengan Penyembuhan Luka

Tabel 3 Perbedaan Perkembangan Fisiologis (Suhu dan RR) Bayi BBLR Setelah Perawatan (Post) pada Kelompok Intervensi dan Kontrol di RSUD Soreang Tahun 2015

\begin{tabular}{llccc}
\hline $\begin{array}{c}\text { Perkembangan } \\
\text { Fisiologis }\end{array}$ & & N & Mean Rank & P Value \\
\hline Suhu & Intervensi & 15 & 23.00 & \\
& Kontrol & 15 & 8.00 & 0,000 \\
RR & Intervensi & 15 & 12.30 & \\
& Kontrol & 15 & 18.70 & 0,037 \\
\hline
\end{tabular}

Tabel 4 Perbedaan Perkembangan Fisiologis (DJ) dan BB Bayi BBLR Setelah Perawatan (Post) pada Kelompok Intervensi dan Kontrol di RSUD Soreang Tahun 2015

\begin{tabular}{llccccc}
\hline $\begin{array}{c}\text { Perkembangan } \\
\text { Fisiologis }\end{array}$ & & Mean & SD & SE & P Value & N \\
\hline DJ & Intervensi & 105,93 & 7,47 & 1,93 & \multirow{2}{*}{0,000} & 15 \\
& Kontrol & 136,93 & 7,05 & 1,82 & & 15 \\
BB & Intervensi & 2188,67 & 194,38 & 50,19 & \multirow{2}{*}{0,155} & 15 \\
& Kontrol & 2094,00 & 158,96 & 41,04 & & 15 \\
\hline
\end{tabular}

intervensi (pre) baik pada kelompok intervensi maupun kelompok kontrol. Denyut Jantung (DJ) bayi pada intervensi adalah 127 dengan standar deviasi 6,14 sedangkan pada kontrol adalah 127,87 dengan standar deviasi 4,63. Hasil uji statistik didapatkan nilai $p$ value 0,666 , berarti pada alpha $5 \%$ terlihat tidak ada perbedaan denyut jantung bayi BBLR sebelum intervensi (pre) baik pada kelompok intervensi maupun kelompok kontrol. Hasil analisis rata-rata Berat Badan (BB) bayi pada intervensi adalah 2128,33 dengan standar deviasi 207,21 sedangkan pada kontrol adalah 2133,33 dengan standar deviasi 184,84 . Hasil uji statistik didapatkan nilai $p$ value 0,945 , berarti pada alpha 5\% terlihat tidak ada perbedaan Berat Badan Bayi (BBLR) sebelum intervensi (pre) baik pada kelompok intervensi maupun kelompok kontrol.

Hasil analisis tabel 3 didapatkan bahwa setelah perawatan (post) mean rank pada Suhu Bayi BBLR Kelompok Intervensi adalah 23 sedangkan pada Kontrol adalah 8. Hasil uji statistik didapatkan nilai $p$ value 0,000 , berarti pada alpha 5\% terlihat ada perbedaan yang signifikan suhu bayi BBLR setelah perawatan (post) baik pada kelompok intervensi maupun kelompok kontrol. Mean rank pada pernapasan setelah perawatan (post) kelompok intervensi 12,30 dan kontrol 18,70 . Hasil uji statistik didapatkan nilai $p$ value 0,037 , berarti pada alpha $5 \%$ terlihat ada perbedaan yang signifikan pernapasan bayi BBLR setelah perawatan (post) baik pada kelompok intervensi maupun kelompok kontrol.

Hasil analisis tabel 4 didapatkan bahwa setelah perawatan (post) rata-rata denyut jantung bayi pada intervensi adalah 105,93 dengan standar deviasi 7,47 sedangkan pada kontrol adalah 136,93 dengan standar deviasi 7,05. Hasil uji statistik didapatkan nilai $p$ value 0,000 , berarti pada alpha 5\% terlihat ada perbedaan yang signifikan denyut jantung bayi BBLR setelah perawatan (post) baik pada kelompok intervensi maupun kelompok kontrol. Rata-rata berat badan bayi post pada Intervensi adalah 2188,67 dengan standar deviasi 194,38 sedangkan pada kontrol adalah 2094,00 dengan standar deviasi 158,96. Hasil uji statistik didapatkan nilai $p$ value 0,155 , berarti pada alpha $5 \%$ terlihat tidak ada perbedaan Berat Badan Bayi (BBLR) setelah perawatan (post) baik pada kelompok intervensi maupun kelompok kontrol.

\section{Pembahasan}

Kondisi BBLR menyebabkan organ tubuh belum dapat berfungsi secara sempurna, sehingga penyesuaian fungsi organ terhadap 
Dwi Hastuti: Hubungan IMT dan Kadar Albumin berhubungan dengan Penyembuhan Luka

perubahan kondisi dari intrauteri ke kondisi lingkungan di luar rahim sangat sulit bagi bayi (Wong, Hockenberry-Eaton, Wilson, Winkelstein \& Schwartz, 2009). Dengan perubahan kondisi ekstrauterin yang berlebihan dapat menimbulkan stres pada BBLR. Respon stres yang dialami pada bayi dapat diamati diantaranya melalui perubahan fisiologis seperti frekuensi napas, nadi, perubahan suhu dan respon perilaku bayi. Selain itu respon stres akan berdampak terhadap transportasi glukosa kedaerah penyimpanan dan dapat menyebabkan gangguan energi berlebihan sehingga dapat menyebabkan hambatan dalam konservasi energi yang dapat memengaruhi pertumbuhan dan perkembanagan bayi (Wong, 2008).

Berdasarkan hasil penelitian perkembangan fisiologis bayi sebelum dilakukan perawatan (pre) terlihat mean rank Suhu Bayi BBLR pada Intervensi adalah 16,03 pada Kontrol adalah 14,97. Hasil uji statistik didapatkan nilai $p$ value 0,735 , hal ini menunjukkan tidak ada perbedaan Suhu Bayi BBLR sebelum intervensi (Pre) baik pada Kelompok Intervensi maupun Kelompok Kontrol. Pada hasil perkembangan Respirasi pada Intervensi adalah 51,80 pada Kontrol adalah 51,27. Hasil uji statistik didapatkan nilai $p$ value 0,796 , berarti hal ini menunjukkan tidak ada perbedaan Respirasi BBLR sebelum intervensi (Pre) baik pada Kelompok Intervensi maupun Kelompok Kontrol. Denyut Jantung Bayi pada Intervensi adalah 127 pada Kontrol adalah 127,87. Hasil uji statistik didapatkan nilai $p$ value 0,666, hal ini menunjukkan tidak ada perbedaan denyut jantung bayi BBLR sebelum intervensi (pre) baik pada kelompok intervensi maupun kelompok kontrol. Hasil analisis rata-rata Berat Badan (BB) Bayi pada intervensi adalah 2128,33 pada kontrol adalah 2133,33. Hasil uji statistik didapatkan nilai $p$ value 0,945 , hal ini menunjukkan tidak ada perbedaan Berat Badan Bayi (BBLR) sebelum intervensi (pre) baik pada kelompok intervensi maupun kelompok kontrol. Hasil penelitian ini terlihat jelas bahwa kondisi BBLR pada kedua kelompok mengalami kondisi fisiologis yang belum stabil Hal ini dipengaruhi oleh beberapa hal salah satunya BBLR sulit beradaptasi ketika lahir oleh karena keimmaturan berat badan sehingga memengaruhi fungsi fisiologisnya.

Intervensi perkembangan merupakan salah satu upaya perawat dalam membantu meminimalisasi stres bayi dalam melakukan adaptasi intrauterin ke ekstrauterin, sehingga diharapkan bayi dapat melakukan adaptasinya dengan baik. Stimulasi taktilkinestetik terbukti dapat memfasilitasi pertumbuhan dan pengaturan perilaku neonatus, bahkan pada neonatus prematur sangat kecil sekalipun (Kusmini, Nurul, M., Sutarmi, 2014). Stimulation tactil-kinestetic intervention dinilai mampu mempertahankan respon fisiologis bayi sehingga dapat beradaptasi dengan baik. Terapi pijat yang berbentuk sentuhan dengan tekanan moderat sebagai intervensi yang meningkatkan pertumbuhan dan sekaligus mengurangi stres karena BBLR menunjukkan respon perilaku yang terkait dengan stres harian rawat inap dan prosedur medis (Anand, 2005 dalam Hernandez-Reif, Diego \& Field, 2007). Respon stres pada bayi akan berdampak terhadap perkembangan fisiologis sehingga berdampak terhadap pertumbuhan dan perkembangan bayi baru lahir. Perkembangan fisiologis bayi dapat dilihat dari perubahan suhu, perubahan pernapasan, dan denyut jantung. Pertumbuhan dan perkembangan bayi dpat dilihat drai respon perilaku dan peningkatan Berat Badan bayi.

Berdasarkanhasilpenelitianperkembangan fisiologis bayi setelah dilakukan perawatan (post) pada kelompok Intervensi dan kelompok kontrol menunjukkan terdapat perbedaan yang signifikan suhu bayi BBLR setelah perawatan (post) pada kelompok intervensi terhadap kelompok kontrol ( $p$ value 0,000$)$. Hasil penelitian ini terlihat bahwa terdapat perbedaan suhu bayi yang diberikan intervensi stimulasi taktil dengan bayi yang tidak diberikan intervensi stimulasi taktil kinestetik, dimana telah ditunjukkan bahwa pada kelompok Intervensi sebelum diberikan stimulasi taktil kinestetik rata-rata suhu bayi 36,06 dan setelah stimulasi taktilkinestetik adalah 36,8. Suhu bayi sebelum diberikan intervensi bayi mengalami hipotermi dan setelah diberikan intervensi suhu bayi adalah normal. Hasil penelitian ini menunjukkan keefektifan intervensi dapat membantu bayi beradaptasi dalam sistem thermoregulasi. Hasil penelitian sesuai 
Dwi Hastuti: Hubungan IMT dan Kadar Albumin berhubungan dengan Penyembuhan Luka

dengan konsep Hikmah E. (2010) yang menyatakan bahwa terapi sentuhan efektif dapat meningkatkan suhu butuh bayi melalui kehangatan yang diberikan. Stimulasi taktil kinestetik yang diberikan merupakan wujud sentuhan halus pada seluruh badan bayi yang direspon oleh otak sehingga akan direspon dan menghasilkan perkembangan kearah yang lebih baik. Teori lain yang mendukung disampikan oleh Meggit (2012) bahwa bayi yang baru lahir sangat sensitif terhadap sentuhan, terutama di wajah, tangan, telapak kaki, dan perut. Pemberian stimulasi taktilkinestetik bersifat sebagai sentuhan sehingga dapat meningkatkan perkembangannya yang ditunjukkan salah satunya adalah bayi merasakan hangat.

Hasil penelitian menunjukkan bahwa perkembangan fisiologis pernapasan bayi setelah perawatan (post) pada kelompok intervensi dan kontrol menunjukkan terdapat perbedaan yang signifikan Pernapasan Bayi BBLR setelah perawatan (post) baik pada kelompok intervensi maupun Kelompok kontrol ( $p$ value 0,037$)$. Hasil penelitian ini menunjukkan bahwa intervensi stimulasi taktil-kinestetik memengaruhi pernapasan bayi dimana pernapasan bayi yang diberikan stimulasi taktil-kinestetik lebih stabil dibandingkan bayi yang tidak dilakukan stimulasi, yang terlihat pada kelompok intervensi rata-rata respirasi sebelum intervensi 51,80 dan rata-rata respirasi setelah intervensi 37,80. Pernapasan bayi yang tidak diberikan stimulasi lebih cepat. Hasil penelitian ini sesuai dengan hasil penelitian Lester, et al. (2011) dinyatakan bahwa stimulasi taktil-kinestetik merupakan perawatan perkembangan yang dinilai dapat memfasilitasi stabilitas fisiologis salah satunya yaitu resipirasi. Intervensi stimulasi taktil-kinestetik dapat meningkatkan perkembangan motorik neonatus BBLR sehubungan dengan meningkatkan respon neuroendokrin pada bayi prematur, sehingga bayi terhindar dari stres yang berdampak terhadap peningkatan respirasi bayi. Pernapasan yang cepat pada bayi akan menimbulkan pemakaian energi berlebih selain itu berdampak terhadap kondisi fisiologis lainnya yang dapat menghambat pertumbuhan dan perkembangan bayi. Pernapasan bayi juga berdampak terhadap sirkulasi oksigenasi bagi metabolisme sel dna jaringan tubuh dalam mencapai pertumbuhan dan perkembangannya. Konsep lain yang mendukung hasil penelitian ini disampaikan oleh Sutarmi (2013) bahwa stimulasi sentuhan dan gerakan yang dilakukan pada bayi dapat berfungsi melancarkan sistem peredaran darah sehingga dapat meningkatkan suplai oksigen dan membantu mengoptimalkan gerakan otot pernafasan pada bayi.

Hasil penelitian perkembangan fisiologis denyut jantung bayi setelah perawatan (post) pada kelompok Intervensi dan kontrol menunjukkan terdapat perbedaan yang signifikan denyut jantung Bayi BBLR setelah perawatan (post) pada kelompok intervensi terhadap kelompok kontrol ( $p$ value 0,000 ). Hal ini menunjukkan bahwa stimulasi taktil kinestetik memengaruhi denyut jantung bayi yang dapat terlihat pada kelompok Intervensi sebelum stimulasi rata-rata denyut jantung bayi 127 dan Rata-rata denyut jantung setelah stimulasi1105,93. Hasil penelitian ini sesuai dengan hasil penelitian Lester, et al. (2011) dinyatakan bahwa stimulasi taktil-kinestetik merupakan perawatan perkembangan yang di nilai dapat memfasilitasi stabilitas fisiologis salah satunya yaitu denyut jantung. Selain itu sentuhan yang diberikan dapat menurunkan respon stres bayi akibat proses adaptasi intrauterin ke ekstrauterin sehubungan dengan meningkatkan respon neuroendokrin pada bayi BBLR yang dapat ditunjukkan denyut jantung bayi bekerja lebih stabil. Temuan lain yang mendukung hasil penelitian ini bahwa sentuhan lembut melalui stimulasi taktil kinestetik telah menenangkan atau mengurangi efek stres pada bayi prematur, mengingat bahwa mereka mengalami banyak stres selama mereka rawat inap (HernandezReif, Diego \& Field, 2007). Dalam penelitian Haley, Beachy dan Ivaskan (2012) juga membuktikan stimulasi taktil pada awal kehidupan menurunkan hormon stres dan meningkatkan mineralisasi tulang.

Hasil penelitian perkembangan berat badan bayi setelah perawatan (post) pada kelompok intervensi dan kelompok kontrol menunjukkan tidak ada perbedaan Berat Badan Bayi (BBLR) setelah perawatan (post) baik pada kelompok intervensi maupun kelompok kontrol ( $p$ value 0,155$)$. Hasil penelitian ini terlihat intervensi 
Dwi Hastuti: Hubungan IMT dan Kadar Albumin berhubungan dengan Penyembuhan Luka

stimulasi taktil kinestetik tidak memengaruhi perubahan berat badan bayi BBLR, walaupun terlihat terdapat peningkatan sedikit pada kelompok intervensi rata-rata berat badan sebelum stimulasi 2128,33 dan setelah stimulasi rata-rata berat badan 2188,67. Hasil penelitian juga tidak sesuai dengan konsep Meggit (2013) yang menyatakan bahwa sentuhan dapat meningkatkan berat badan bayi. Banyak faktor yang memengaruhi perkembangan berat badan bayi salah satunya yaitu status nutrisi (Riyadi \& Sukarmin, 2009; Hockenberry, Wilson, Winkelstein, \& Kline, 2009; Jitowiyono \& Kristiyanasari, 2010). Dalam penelitian ini bayi sebagian besar diberikan susu formula, setelah dilakukan wawancara terhadap ibu bayi sebagian besar ibu tidak maksimal memberikan ASI dikarenakan ASI yang keluarnya sedikit. Hal ini yang memengaruhi bayi BBLR mengalami kesulitan untuk mengejar berat badannya yang kurang. Tindakan asuhan keperawatan dalam hal ini untuk mengoptimalkan status nutrisi bayi diperlukan kerja keras perawat dalam memotivasi dan meningkatkan pengetahuan orang tua bayi sehingga ibu bayi mampu memberikan nutrisi ASI secara optimal.

\section{Simpulan}

Berdasarkan hasil penelitian maka tujuan dalam penelitian terjawab dimana ditunjukkan bahwa Perbedaan perkembangan fisiologis dan berat badan bayi BBLR sebelum intervensi (Pre) adalah tidak ada perbedaan suhu bayi BBLR sebelum intervensi (pre) pada kelompok intervensi dan kelompok kontrol ( $p$ value 0,735$)$; tidak ada perbedaan respirasi BBLR sebelum intervensi (pre) pada kelompok intervensi dan kelompok kontrol ( $p$ value 0,796 ); tidak ada perbedaan denyut jantung bayi BBLR sebelum intervensi (pre) pada kelompok intervensi dan kelompok kontrol ( $p$ value 0,666 ); tidak ada perbedaan Berat Badan Bayi (BBLR) sebelum intervensi (pre) pada kelompok intervensi dan kelompok kontrol ( $p$ value 0,945). Adapun perbedaan perkembangan fisiologis dan berat badan bayi BBLR setelah intervensi (post) yaitu ada perbedaan yang signifikan suhu bayi BBLR setelah perawatan (post) pada kelompok intervensi dan kelompok kontrol ( $p$ value 0,000$)$; ada perbedaan yang signifikan pernapasan bayi BBLR setelah perawatan (post) pada kelompok intervensi dan kelompok kontrol ( $p$ value 0,037); ada perbedaan yang signifikan denyut jantung bayi BBLR setelah perawatan (post) pada kelompok intervensi dan kelompok kontrol ( $p$ value 0,000$)$; tidak ada perbedaan berat badan bayi BBLR setelah perawatan (post) pada kelompok intervensi dan kelompok kontrol ( $p$ value 0,155$)$.

Perawat dan keluarga diharapkan dapat memberikan stimulasi taktil-kinestetik secara langsung baik selama bayi di rawat dirumah sakit maupun di rumah, karena intervensi ini karena selain berdampak terkait perubahan fisiologis bayi, sentuhan yang diberikan juga menimbulkan psikis bayi menjadi nyaman, aman dan tenang sehingga menimbulkan hubungan orang tua dan bayi lebih terjalin dengan baik. Disamping itu untuk meningkatkan berat badan bayi diharapkan ibu dapat memberikan nutrisi ASI kepada bayinya secara optimal.

\section{Daftar Pustaka}

Aliabadi, F., \& Askary, R.K. (2013).Effects of Tactile-Kinesthetic Stimulation on Low Birth Weight Neonates. Original article,23, 289-294. Published by: Tehran University of Medical Sciences.Diperoleh tanggal 2 Januari 2014.darihttp://ijp.tums.ac.ir.

Bobak, Lowdermilk, \& Jensen (2005).Buku Ajar Keperawatan Maternitas, Wijayarini. M.A., \& Anugerah, P.I. (alih Bahasa), Jakarta: EGC.

Haley, S., Beachy, \& Ivaskan (2012). Tactile/ kinesthetic stimulation (TKS) increases tibial speed of sound and urinary osteocalcin (U-MidOC and unOC) in prematur infants (29-32 wks PMA).Bone. Author manuscript; available in PMC 51(4): 661-666. Diperoleh tanggal 1 Januari 2014, dari http://www.ncbi. nlm.nih.gov/pmc/articles/PMC3434881/pdf/ nihms-397265.pdf.

Henderson, C.,\& Macdonald, S. (2005). Mayes'Midwefery., A Textbookfor Midwives. 
Dwi Hastuti: Hubungan IMT dan Kadar Albumin berhubungan dengan Penyembuhan Luka

Britis: Elsevier.

Hernandez-Reif, M., Diego, M., \& Field, T. (2007).Preterm Infants Show Reduced Stres Behaviors and Activity after 5 days of Massage Therapy.Infant Behav Dev. 30(4).557-561. Diperoleh tanggal 2 Januari 2014, dari http://www.ncbi.nlm.nih.gov/pmc/ articles/PMC2254497/pdf/nihms33982.pdf.

Hikmah, E. (2010) .Pengaruh terapi Sentuhan terhadap suhu dan frekuensi nadi bayi premature yang dirawat di ruang perinatologi RSUD Kabupaten Tangerang.https://www. google.co.jp/?gws_rd=ssl\#q=pengaruh+tera py+sentuhan.

Jitowiyono \& Kristiyanasari (2010). Asuhan Keperawatan Neonatus dan Anak. Yogyakarta: Numed.

Kachoosangry, R.A., \&Aliabadi, F. (2011). Effect of Tactile-Kinestetic Stimulation on Motor Development of Low Birth Weight Neonatus.Iranian Rehabilitation Journal, 9, 16-18.Diperolehtanggal 17 Februari 2014, dari http://irj.uswr.ac.ir/files/site1/user files $055690 / \mathrm{admin}-\mathrm{A}-10-1-48-4 \mathrm{c} 85 \mathrm{ab} 1$. pdf.

Kusmini, Nurul, M., Sutarmi (2014). Modul Touch Training: Developing Baby Massage, Therapy Massage for Baby and Spa.,upublised internal used only.

Lester, B.M., Miller, R.J., Hawes, K., Salisbury, A., Bigsby, R., Sullivan, M.C., et al. (2011). Infant Neurobehavioral Development.Semin Perinatol. 35(1): 8-19. Diperoleh tanggal 6 Maret 2013, dari http:/www.ncbi.nlm.nih.gov/pmc/articles/ PMC3168949/pdf/nihms261929.pdf .

Lissauer, T., \& Fanaroff, A. (2006). At A Glance Neonatologi, Umami, V. (2009) (alih Bahasa), Erlangga: Jakarta

Meggit, C. (2012). Memahami Perkembangan Anak, Theodora, W.A. (2013) (alih Bahasa), Jakarta: PT Indeks

Papalia, Olds \& Fieldman, (2013).A Child's world, infancy through adolescence (9th ed). New York: The McGraw-Hill Companies,Inc

Reynolds, C.R., \& Janzen- E.F. (2007). Encyclopedia of Special Education (3th ed), 1. Canada: John Wiley.

Riyadi, S., \& Sukarmin (2009).Asuhan Keperawatan pada Anak. Yogyakarta: Graha Ilmu.

Sutarmi (2013).Standart Operating Prosedur Kiddy Healthy and Baby Spa., upublised internal used only.

Wong, D.L., Hockenberry-Eaton, M., Wilson, D., Winkelstein, M., \& Schwartz, P., (2009). Buku ajar keperawatan pediatrik (6 $6^{\text {th }}$ edition). Sutarna, N., \& Kuncara (alih bahasa). Jakarta: EGC. 